\title{
Billedskæreren Hans Dreyer.
}

\section{Af Carsten Petersen.}

En af de forste Dage i Aaret 1653 var en talrig Forsamling til stede i Oksenvarl kirke (Haderslev Provsti). Det var sogneprestens Fader, som blev stelt til Hvile, den gamle Billedskærer Hans Dreyer.

Sorgetalen blev holdt af Husets V'en, Naboprosten Peder Wandal fra Magstrup"). Den blev trykt paa Tysk og ulkom, saasnart $\mathrm{Hr}$. Peder kunde faa den færdig, i Rostock samme Aar. I Oksenvad Kirke har Pastor Waudal dog nuligvis talt paa Dansk.

Efter Tidens smukke Skik bred selve Ligtalen sig ikke dit mindste on den afiøcles Person, nævner ham slet ikke, men $i$ et kort Tillog er vedfojet, hvall man mente, der kunde og burde siges om ham. Dette lille Levnedslob i korte Træk skal her meddeles i dansk Oversattelse og tjene som Ranme for det $f\left(l^{-}\right.$ gende**).

Persollalia.

Hvad angaar vor i Gud hvilente Medbroder M. (Nester) Hans Ireyers celige Herkomst, kristelige Liv og salige Ende, da har vi derom god Efterretning, at han er avlet og fodt i Eckernforde i Holsten Anno 1572 af fornemme Gud og Erekare Forallire. Hans s. Fader var den Hrederlige, Velagtede og Velfornenme Peter Dreyer, Borger, Bonde og Købmand i Eckernforde; Hans s. Moder er den fordum Ere-

-) Se om ham: Poder J. Wandal, et Prastelir i det 17 . Aarlundresie, af Carsten Petersen. 19924.

" En Grel'sartelse af Mag. Jellsen findes i „Fra Arkiv og Muscilma V. 
og Dyderige Fru Margrete Tape. Belstefaderen paa Faderens Side er den fordum Hæderlige, Velagtede og Velfornemme Klaus Dreyer, Borger og Kobmand i Eckernførde. Bedstemoderen i Fædrenelinje er de: fordum Are- og Dyderige Fru Adele Borns. Bedstefaderen til Moderen or den Hæderlige, Velagtede on Velfornemme Klaus Tape, Borger og fornem Kohnand i Eckernforde. Bedstemoderen paa Moderens side var den Ere og Dyderige Fru Adel Ahrens, den fordum Hæderlige, Hojagtede og Hojvise Herre Jorgen Ahrends, den hojt fortjente Borgermester i Eckernforde, hans agtefolte Datter. Af disse Gud or -Erekære som ogsaa Velfornemme Forældre er vor S. Medbroder fadt og lige straks efter Fodselen fort til den Herre Jesus ved den hellige Daab og da ogsaa blevet flittig opdraget i Gudfrygtigheden. $\mathrm{Og}$ efter at han havde temmelig lagt Fundamenta $i$ Lxsning, Skrivning og Regnekunst, blev vor $S$. afdøde Anno 1586 efter hans kxre Forreldres tidlige og dodelige Bortgang af de efterladte Venner i Blodet betroet til den kunstrige Billedskarer Mester Syrack Dyrichsen for at lære Billedskærerkunsten, hos hvem han efter sit Larebrev med Ros havde udstaaet sine 7 Læreaar, har derefter rejst frem og tilbage $i$ Tyskland for videre at fortsæette sin Kunst og er endelig igen kommen tilbage in patriam til segeberg, har arbejdet sammesteds nogle Aar, lerefter begivet sig til Lybæk, gjort sit Mesterstykke dersteds og ladet sig optage i deres Billedskærer- og Snedkerlav og indtil clen Dag i Dag holdt det med det lybækske Amt som ogsaa liar elsket og ælet ham som en Mester og Medbroder som om han var paa Stellet, hvad de vekslede Breve og eksisterende Testimonia 
udviser. Anno 1602 har han indladt sig $\mathrm{i}$ et kristeligt Egteskab med den .Ere og Dyderige Jomfru Katharina Kiuse, avlet med hende 3 sonner, den æluste Kristian var i nange Aar ansat som Impensionarius paa den kongelige Gaard Hall 3 Mil fra Rendsborg, som dode saligt i Herren samnesteds Anno 1641. Den mellenste, Peter ved Navn, dode da han var halvandet Aar gammel. Den yngste Henrik havde Lyst til Krigen. Anno 1637 var han unler den Kejserlige Armee horporal til Hest, fra den Tid har man ikke haft rogen Efterretning fra ham. Da Anno 161k hans $S$. Hustru blev taget bort fra hans Side, skred han Anno 1616; til andet Agteskab med den Ere og Dyderige Jomfru Anna Martens, hvis Egteskab blev velsignet med 3 sonner og 3 Dotre, de 2 sonner hvile hos Gud, den ene Son M. Petrus Dreyer Prast hersteds, den reldste Datter Margaretha er H. Paul Astraten's Agtehustru og Maria D. Otto Johann schultze's Agtehustru, Canonirus i Braunschweig, og Jomfru Elena er endnu i Live.

Hvad hans Kristendom angaar, saa har han forholdt sig saaledes, at enhver af hoj eller lav Stand maa give ham det bedste Vidnesbyrd. Paa Grund af sin Kunst, Flid og Oprigtighed èr han blevet elsket meget af Adel og Uadel, at hans Navn har lydt hid og dicl og er blevet kaldet af efterfolgende Velbaarne Hoj og Velædle Faste Huj og Mandhaftbaarne Herrer, den kongel. $H$. Statholder forlum Gert Rantzau har han arbejdet for 5 Aar paa Silkeborg i Jylland og 2 Aar paa hans Gods Kantzau. Derefter H. Oluf Rosensparre paa Vallø i Sjelland 2 Aar. Saa var det. hojbemeldte kong. Statholder H. Gert Rantzau Anno 1017 vocerede ham med Kone og Born fra segeberg 
til Haderslev for at han der skulde vare kongelig beskikket Hof-Billedskærer. Kort efter havde H. Eskr Brok paa Dronningborg Bud efter ham og arbejdelle for han af og til i 18 Aar. Derfra H. Peter Munk paa Sxbygaard 2 Aar, H. Holger Rosenkrants paa Dalum 2 Aar, H. Henrik Rantzau paa Mogelkjæx i Jyllanl 2 Aar, den kongel. Statholder H. Frants Hantzau i København 2 Aar, Fru Ellen Marsvin i Fyn paa Ellensborg 7 Aar, H. Jorgen Schult paa Finstrup i Fyn 1\% Aar. Tilsidst H. Frants Lykke i Fyn 3 Aar. Hvem kan fortalle alt hval for smukke Irbejder han har efterladt hos os og $i$ vore hirker. Vi maa slutte med hans $s$. Ende, fordi han var meget ganmel, log med Arbejlet og synet, hvilke var (iuds sarlige Gaver, kumle komme langt forud for mangt et ungt Menneske, har hans hjertenskre son M. Гetrus Dreyer barnligt anmodet ham at komme til ham fra Fyn, fra det fremmede, og i Betragtning af hans høje Aller begive sig til Ro, har han endeligt for 1 Aar siden omtrent indvilliget deri. Faar nu sidst paa Nyaarsmorgen i Kirken en Frost, gaar hjem ong bliver sengeliggente, lacler sig forsone mell Kristo ved d. h. Nadver clen folgende Tirsclag, bedler flittigt bl. a. de kare Julesalmer: Lovet vare du Jesus Krist - Fra Hinlen lojt - Ak, hjertekare Jesus - siger derefter God Nat til alle og taler derefter med tydelig Rost: Herre Jesus i dine Hander befaler jeg min Aand, sov saa saligt hen i Kristo Jesu straks derefter paa hans Sygdoms den tredje Dag, nemlig d. 3. Jan. uden at have faaet Krampe i Hrender og Fodler i sit 81. Aar.

Taalmodighedens og Trostens lader ville trostc den efterladte dybtbedrovede Enke og Born, skanke 
det udleveik Legeme en stolt Hvile i Jorden og paa hin store Dag ell gladelig Forbindelse af Legeme og Sjacl, ogsaa give os allesammen en salig Time at leve og do, paa den yderste Dag en gladelig Opstandelse til det evige Liv for Kristi Opstandelses skyld, til hvilken opstandne Sejrsfyrste vi vil henvende os med et tillidsfuldt

Fa de r vor.

Hvad her er fortalt, hviler altsaa paa Papirer og Optegnelser, som forefandtes i Hjemmet efter den gamles Dod. For den, som forsnger at underkaste Fremistillingen en historisk Prove, viser det sig, at Meddelelserne i reres Helhed stemner overens med, hvad der ellers er kendt om de faktiske Forhold, ikke hlot med Hensyn til Omrablet for Hans Dreycrs Virksomhed, men ogsaa med Hensyn til Rakkefølgen af de Navne, der er novit. En Del Navne er dog aabenbart glemte eller udeladte sarlig fra let sidste Tilsrum, rimeligvis fordi Virksomheden da var mere spredt og paa enkelte steder kortvarig.

Vi staar overfor en Kunstnergerning af ikke ringe Omfang baale i Tid og Rum. Fra IIolsten til Limfjorden, fra Toftlund og Gram til Kobenliavn har denne Mand sat sine Spor.

Men ser vi nojere til, bliver der narmest Tale om to Omraader, nemlig Fyn og den nordligste Del af Sønderjylland, det gamle Hallerslev Provsti (ned ile otte Sogne ind til Kolding). Her maa vi forsoge at fincle den store Restbeholdning af Hans Dreyers Kunst.

Da staar vi med det sanme over for en Vanskelighed, der dog ikke er helt enestanende i Kunstens Historie. Hval der nemlig efter mit Skrn maa hen- 
fores til Hans Dreyer af nu eksisterende Billedskaarbejder paa begge sider af Beltet er saa forskelligt i Stil og Udforelse og hinanden saa uligt, at man kun modstrabende vil tilskrive det altsammen et oy samme Varksted. Da jeg efter at have gjort mig noget Begreb om, hvad der i Sonderjylland kunde bringes i Forbindelse med Hans Dreyer, for forste Gang saa et Billede af det rige Udstyr i Holckenhavns Kapel, maatte jeg uvilkaarligt ulbryde: Det er umuligt; det kan ikke være den samme Kunstner. Og da jeg beskedent fremstillede mig for de sagkyndige $i$ Nationalmuseet i København og vovede, at udpege den dem velkendte Mester som den, der havde udført adskillige af vore nordslesvigske Altertavler, molte jeg megen Hovedrysten.

Nu vel, visse Ting kan man blive enig om gennem Forhandling. Andre Ting kan man enes om, fordi man tvinges til det. Vi kommer her til at slaa ind paa den sidste af de to Veje.

Der er mig bekendt ingen mere, som betvivler Sammenhængen for Holckenhavns Vedkommende Det er Hans Dreyers Haand, som har arbejdet i Ellen Marsvins Kapel. Det er altsaa vest for Beltet Tvivlen ligger, og det bliver min Opgave her, muligvis at skaffe Bevis for, at den Mand, som har arbejdet i Nyborg er den samme, som den der har skabt en Del Altertavler o. s. v. i Haderslev Provsti, eller at i alle Tilfælde den sidste af de to er Hans Dreyer fra Eckernforde.

Jeg tager Tyren ved Hornene; det er bedst.

Stilspørgsmaalet og hvad dertil hører lader jeg ligge indtil videre. Jeg lader, som om jeg ikke kender eller ikke forstaar den Side af Sagen, for ufor- 
styriet at kumne lytte til, hvad Historien siger. Det er følgende.

1. Efter de ovenanfurte Personalia har Hans Dreyer været antaget som Hofbilledskærer paa Haderslevhus fra Aaret 1617. Dette bekrixfes af slotsregnskaberne.

2. Statholderen Gert Rantzau, som kaldte den Dreyer'ske Familje herned fra Holsten, var som Kongens Lensmand Kirkepatron i Haderslev Provsti og selvskreven som øverste Myndighed og Tilsynsmand over alle de Kirker, som var sluttede sammen i Provstiets fælles Kirkekasse. Det laa altsaa for ham akkurat lige saa nær at bruge Billedskæreren til Kirkearbejile som til Slotsarbejde. Tilmed ved vi, at Beskaftigelsen paa slottet kun krævede et ringe Antal Dage om Aaret, for denne stillings Skyld kunde man ikke forsvare at hente hele Faniljen herop.

3. Styrelsen for Irovstiets Kirker har i første Halvdel af 17. Aarhundrede aabenbart planmassigt fornyet Kirkeinventariet. Det er nærliggende, at en og samme Kunstner har udfort hele Arbejclet. Ogsaa fra en noget senere Tid ved vi, at der var en fastiønnet Snedker ved Provstiets Kirker. Dette bliver endnu mere sandsynligt, naar man lægger Mærke til at alt, hvad der udføres af Kunstnerhaand, er ligeligt fordelt paa et Tidsrum 1607-1624. Det hele er just gaaet saa hurtigt, at et og samme Værksted kunde overkomme det.

4. Hvad der synes at pege lige paa Hans Dreyer, er den Omstændighed, at intet Arbejile navnes mere 
fra Begyndelsen af Kejserkrigen til Aar 1637 den Tid, da han var i Kobenhavn og Nyborg.

5, Saa er ilet, vi hører Peder Wandal sige: "Hven kan fortalle alt, hvad for smukke Arbejiler, han han har efterladt hos os og i vore Kirker." Sagt paa det sted, hvor det blev sagt, kan det kun betyde: Kirker i Omegnen af Oksenvad og Magstrup. Det er klart, at alle Tilhorere i Oksenvall Kirke har vidst Besked om, hvad Prasten mente.

i. Pastor Bojsen d. y. i Magstiup, fra hvis Haand vi har en Del Optegnelser om Magstrup og ancle Sogne, omtaler ogsaa Mester Hans Dreyer og siger: Ja, det smukke Arbejde i vor herverente Kirke er fra ham.*) - Det er vel nedskrevet langt senere i Tiden; men Bojsens Fader var Prast i Magstrup allerede 1693, altsaa 40 Aar efter Dreyers Død.

7. Hvis ikke de mange Altertavler og Prodikestole fra 1. Halvdel af det 17. Aarhundrecte i Omegnen af Haders]ev er af Dreyer, saa bliver der ikke Plads for noget fra hans Haand. Da er det ell Umulighed, at han har leveret noget som helst tif disse Kirker, da har Peder Wandal staaet i Oksenvad Kirke og snakket hen i Taaget.

Disse Kendsgerninger taler deres Sprog. For mig or de overbevisende og tvingende. Der er ingen Vej uden om.

Vi tvinges til at erkende, at Altertavien i Magstrup Kirke er Hans Dreyers Værk, at ikke faa ancle Kirker paa Egnen har varet smykkede af den samme Haand, og at der, hvis dette er rigtigt, da kun kan

*) Disse Papirer ophevares i Ribe hatedralskole. Gronlund's Saml. Pakke VI. 
være Tale om de mange Genstande, som paaviseligt er anskaffede i 1. Halvdel af det 17. Aarhundrede og endnu forefindes.

Efter Tidens skik forsømte man ikke at forsyne Kirkernes Indre og Ydre med Navne paa Provster, Præster, Kirkeværger o. s. v. Men hverken i Kirkerne eller i Kirkernes Regnskabsbøger møder vi Hans Dreyers Navn. Kunstneren forsvandt beskedent bag sit Kunstværk. Og hvis den gamle vidste, hvad jeg her har for, vilde han sagtens bede sig forskaanet. Jeg forstaar dig godt, Hans Dreyer, men det hjælper ikke. Tilleme skifter. Nutildags maa vi allesammen i Avisen.

Saa skal jeg forsuge at give et Overblik over Mandens Gerning.

Det var i Aaret 1602, han giftede sig med Jonifru Katrine Kruse. Det var formodentligt paa den Tid, han indrettelle sit furste Værksted i Segeberg. Da var han altsaa 30 Aar. Han sluttede sig til Billedskærerlavet i Lybæk, og efter den gamle Lavsbog fra 1528-1619 har meyster Hans Dreyer vann Segeberge 1. 20. Marts 1610 sluttet Overenskomst med Lybækkerne, at han vil antage og løssige sine Lærlinge ved Amtet der. Samme Bog viser ogsaa, at Mesteren har antaget en Lærling ved Navn Jürgen Voderbarch paa 4 Aar ved Juletid 1608 og en anden ved Navn Friedrich Cato paa (i Aar om Efteraaret 1610.*) Jeg har disse to unge Helte mistænkt for at have forsynet Altertavlerne $i$ vore Kirker med adskillige Figurer, som jeg og mange andre kunde have gjort ligesaa daarlige.

•) Medd. ira Statsarkivet i Lybæk. 
Der maa vel være Kirker i Omegnen af Segeberg. hvor Hans Dreyer har arbejdet, men jeg formaar ikke at navngive nogen. Professor Haupt har slet ikke opdaget denne Kunstner, hverken i Slesvig eller Holsten, og jeg har ikke i de holstenske Partier af hans store Værk, fundet noget, som med Sandsynlighed kunde være udgaaet fra Værkstedet i Segeberg. I de store Museer i Kiel og Flensborg har jeg heller ikke truffet Genstande fra Dreyers Haand. Thaulowmuseet gemmer Billedskærernes Lavsbog fra Eckernforde, men desvarre begynder den først efter Aar 1600, da Hans Dreyer havde forladt sin Fædreneby.

Allerede tidligt fik Hans Dreyer Forbindelse med det nordligste Slesvig og Jylland. Eske Brok døde 1625. Da havde den holstenske Kunstner arbejdet for ham lejlighedsvis i 18 Aar. Vi naar da tilbage til Aaret 1607. I Nordslesvig moder vi dette Tal paa en Prædikestol i Bjert Kirke. Dette er Dreyers første Arbejde i Haderslev Provsti, et rent Renaissancearbejde.

I Fyldingerne mellem 6 korintiske Søjler staar 5 kraftige Figurer: Kristus og de fire Evangelister. Kristusfiguren bærer Rigsæblet i venstre Haand, mens den højre er oprakt til Velsignelse (i Lighed med mange gamle Bispe- og Pavebilleder). Om Hovedet ser vi en Straaleglorie, som løber ud i tre (egentlig fire) Spidser, mindende om visse bekendte Ordensstjerner. Evangelisterne er forsynede hver med sit Sindbillede. Englen hos Matthæus er blevet til en lille Tjener, som staar ved sin Herres Side og rækker Blækhornet op til ham. Markus bærer selv Blækhuset i en Snor om Livet, mens Løven ligger bag ved ham. Lukas træder med den ene Fod paa 
en Bog, og Oksen ligger ved hans Fod. Johannes, som i Modsætning til de andre tre er uden Skrg, staar med opadvendt Ansigt og højre Haand paa sit Bryst; Ørnen sidder rolig ved hans Side.") Lydhimlen er omgivet af mange smaa Gavle og Spir og barrer Bogstaverne D G S og P H. Hele Værket er kraftigt og smukt profileret. Det trænger kun til at iklades de oprindelige Farver for at blive en værdig Pryd for den store Kirke.

Kirken i Gammelhaderslev har en Prædikestol, som paa 2 Steder bærer Aarstallet 1(i09, sikkert et Bevis paa, at den i Tidens Løb er blevet omarbejdet. Haupt finder nogen Lighed mellem denne og den Bjerninger Prædikestol, og jeg mener i Samklang hermed, at begge maa henregnes til den Dreyerske Gruppe. Desuden har Haupt i samme Kirke set en Altertavle, som skulde være omtrent fra samme Tid. Den maatte da ogsaa antages at være af samme Mester. Nu findes Altertavlen ikke mere paa sin Plads, og jeg ved ikke, hvor man skal søge den.

Det følgende Aar fik Kirkerne i Magstrup og Skodborg nye Altertavler. Det er Renaissanceværk begge Steder, lige som alle de øvrige Arbejder $\mathbf{i}$ disse Kirker, saa vidt de formentligt bør tilskrives Hans Dreyer. Hvad vi her ser af Figurer: Fire Dyder (Skodborg), et Par liggende Figurer, som flankerer den overste Gavl og et Par menneskelige Ansigter, som titter gennem runde Aabninger i Sidefløjene (Magstrup), er tarveligt Lærlingearbejde. Men set paa Afstand og farvelagt kan de virke oplivende. De arkitektoniske Partier, som er Hovedsagen, er alle-

") Hvem der ønsker Forklaring til Enkelthederne kan henvises til Profeten Ezechiel c. 1 v. 10 og c. 9 v. 2. 
vegne kraftige, vel proportionerede, solidt sammenfojede, afpassede efter Rummet og ikke uden storladne Linjer. Ein stattliches Werk - kalder Haupt det i Skodborg. Tandsnit og Kartucher er anvendte nued Forkærlighed. Det store malede Billede i Midten forestiller den h. Nadver.

Nordost for Magstrup ligger Nabokirken i stepping. Her staar en smuk Altertavle fra 1612. Den har et Par Ejendommeligheder frem for dens siaskende i Magstrup og Skodborg. Gennem den brudte (iavl*) rejser sig et Krucifiks, som giver Mirltpartiet sin overste Afslutning. Men hvad der særlig giver hele Varket Karakter, er dets Dybde. De joniske Sujler er rykket et Stykke frem fra Baggrundens store Flade og Bjælkelaget oven over bærer et buet Loft, en Himmelhvalving. Der er opstaaet en lille Arka(lebygning, et Telt, et Tempel, Billedskæreren er blevet til en Bygmester, og man kunde onske, at han var gaaet videre ad den Vej.

Imidlertid leverede Mesteren sanme Aar et Arbejde, som viser hans Kunst fra den modsatte side, nemlig Prædikestolen i Starup Kirke ved Haderslev Fjord. Her møder vi det første (og eneste) os bekendte Reliefarbejde fra dette Værksted paa slesvigsk Grund. Det er umiskendeligt Mesterens egen Haand, som har virket her fra først til sidst, og vi kan ikke llægte ham den Anerkendelse, som han fortjener. Seks Søjler af en sjældent smuk Form med joniske Kapitæler og Vaabenskjolde bærer smaa Brystfigurer, hvorpaa Prædikestolens øverste Ramme hviler. Fyldingerne imellem disse Søjler er optagne af Her-

*) Fn lignende gennembrudt (Gavl ses paa en Altertavle af $\mathrm{H}$. Ringering, som opbevares paa Museet i Flensborg. 
ren og de fire Evangelister i Relief med Baldakiner. Naar vi tager disse fem Partier lidt nøjere $i$ Øjesyn, opdager vi snart en paafaldende Lighed med de tilsvarende Partier paa Prædikestolen i Bjert. Kristus bærer Rigsæblet i den venstre Haand, den højre er løftet til Velsignelse, og om Hovedet er der en i tre Spidser udstraalende Glorie, aldeles som i Bjert. Matthæus har Englen staaende bag ved sig, en redebon og maaske tillige inspirerende Tjenerskikkelse, der (som i Bjert) rækker Blækhuset frem med den ene Haand, mens han betænksomt med den anden drager det tunge røde Klædebon tilside, som hindrer Evangelisten i at skrive. Markus udmærker sig ved sin ridderlige Dragt. Lukas blader med sine smalle Fingre i en Bog, han maatte jo læse, hvad andre havde skrevet før ham, og Johannes er atter den stille skuende Tænker og Kærlighedens Teolog, der vender Ansigtet opad, mens venstre Haand ligger paa Brystet. Sindbillederne er naturligvis ogsaa de samme som i Bjert. Men her ligger de tre Dyreskikkelser under det Bord, ved hvilket Evangelisten sidder. Kun deres Hoveder titter frem under den opløftede Borddug. Ørnen er elegant og fint skaaret. Løven skrækindjagende. Men Oksen ser saa kvik og fornøjelig ud, at ingen Præmieokse fra det 20. Aarhundrede kan stilles ved Siden af den. - Der paastaas, at der ogsaa har været en Indskrift paa Tysk, som senere er tilintetgjort. Denne Indskrift kan jo godt tænkes gjort af Hans Dreyer, som vist aldrig fik lært at skrive dansk.

Vi maa nu følge Kunstneren paa en Rejse nordpaa. Det er længe siden, Hans Dreyer første Gang lod sig se paa Silkeborg- og Randersegnen. Men det 
er forst Aar 1613, vi kan spore ham. Paa Dronningborg ved Randers levede Kongens Lensmand Eske Brok, Herre til Estrup og Rigsraad. Denne Herremand havde Fornøjelse af at optegne Livets Hændelser og egne Bedrifter i en Dagbog. Vi tænkte, da disse Dagbøger - som de fleste - handler om ringe Ting, om ikke det ringe Navn Hans Dreyer skulde findes $i$ dem. Det viser sig nu, at $i$ de Papirer, som omfatter Tiden 1604-12 har hverken Manden eller hans stille Gerning kunnet naa op paa Siden af de mindeværdige Jagtpartier eller Løjerne ved Gildesbordet. Men i Efteraaret 1613 møder vi disse Optegnelser: Okt. 30 - ved Erich leffuerit Mester Hans Snedker 30 Slette Daller. Og derefter: "Dec. $24-$ sende jeg Mester Hans Snecker medt lille Karen Nielsdatter fiortten slette Daller pa Arbeydt och var dett for de 4 skrine, handt da haffde fierdig; och var $3^{1 / 2}$ Daller for hvert skrin. E. B. e. H.« Senere kommer Hans Snecker endnu en eneste Gang: "1622 d. 19. Maj betalte jeg Hans snecker j Randers 6 Mark for en hjortetackes hoffuet hand udskar, och nogit tilforn och 6 Mark for itt andet«. Trods det, at Værkstedet endnu var i Segeberg, har han selv paa den Tid aabenbart opholdt sig paa det Sted, hvor hans Arbejde blev begæret. Dette gælder formodentligt om alt hans Arbejde paa Herregaardene, hvilket ogsaa bekræftes af Ligtalen.

Her maa være Plads til et Par Bemærkninger om, hvorledes Hans Dreyer kan tænkes at have vundet Indpas paa de mange danske Herregaarde.

Det maa sikkert have været Gert Rantzau, som først havde Brug for ham. Da Hovedsædet Rantzau ligger i Holsten (11/2 Mils Vej fra Pløn), behøvede 
Herremanden ikke at søge længe for at finde en Billedskærer i Segeberg. I to Aar havde den unge Kunstner den $A$ Ere at arbejde paa det holstenske Slot. Men samme Gert Rantzau var ogsaa forlenet med Silkeborg, og her maa have været meget at forrette, da Hans Dreyer maatte anvende 5 Aar paa denne Opgave. Fra Aar 1599, da Faderen døde, var Gert Kongens Statholder i Hertugdømmerne og har vel fra det Tidspunkt haft sin Residens paa Haderslevhus. Han vedblev at være Hans Dreyers Beskytter, og da Herremanden stod $\mathrm{i}$ Yndest og Anseelse hos Christian IV, om ikke for andet saa for hans Bedrifter under Kalmarkrigen, faldt ogsaa lidt af den kongelige Naade paa Billedskæreren; Hans Dreyer kom til at arbejde for Kongen af Danmark. Og saa for adskillige høje Herrer i Kongens Raad.

Eske Brok havde kendt ham længe, maaske fra hans Ophold i Silkeborg. Ogsaa han har formodentlig været en Anbefaler. Thi Hr. Eske paa Dronningholm var en meget god Ven af Oluf Rosensparre paa Vestervallø, og den unge Sten Rosensparre blev trolovet med den jyske Herremands Datter. Allerede 1604 melder Dagbogen om, at de to Familjer havde det rart sammen. "Den 10. (Jan.) kom Olluff Rosenspar och Lyssebett hidt til mig. Druchett en snessert med honom". Senere rejste Herrerne til Viborg Snapsting og her steg Snesserten til en regulær Rus: »Drak med Preben och O. R. itt rus- + « (med et Kryds). Derefter: "Drack med O. R. udi hans Lossement itt rus- ++ « (med 2 Kryds). I slige lykkelige Timer nøjedes man vel ikke med at tale om Bønder og Stude, men Stemningen løftede sig op til 
Kunstens lyse Egne. Saaledes svævede Hans Dreyers Navn fra Jylland til Sjælland.

Paa Fyn levede »den rige Frans Lykke«, Ejer af 12 Herregaarde. Hans Frue var en Datter af Eske Brok. Og paa de mange Slotte var der jo nok at bestille.

Saa behøvede Hans Dreyer vist ikke flere Anbefalinger.

Fra Dronningborg, hvor vi har fejret Jul 1613, vender vi nu vore Skridt igen hjemad mod Segeberg. Der ligger en Skygge paa vor Vej; om Billedskæreren har bemærket den, ved jeg ikke. Men i det kommende Aar døde hans Hustru Katrine Kruse bort fra ham og sine smaa Børn.

Altimens gik dog Arbejdet sin Gang paa Værkstedet. En Altertavle til Øsby sydfor Haderslev Fjord blev færdig 1614. Øsby Kirke er en af de største i Provstiet; den har en usædvanlig Højde og respektable Hvælvinger. Mesteren, som øjensynligt allevegne søgte at udfylde al den Plads som stod til Raadighed, havde her et ualmindelig stort Spillerum. Det nye Værk, skønner jeg, maa i Fladeindhold have været det største af alt, hvad han har leveret til Nordslesvigs Kirker. Maa have været ja, thi nu er der handlet ilde med det. Der, hvor det nu har sin Plads, nemlig i Jegerup Kirke, er Rumforholdene for smaa. Et godt Stykke af Foden (ogsaa Søjlernes Fodstykker) er savet af og hele Toppen er fjernet. Hvad skulde man gøre andet? Endda maa man tage Hatten af for den gamle Kæmpe. Svarende til den betydelige Bredde dannes Hovedpartiet af 4 korintiske Søjler, og disse er i Lighed 
med Stepping stillede ca. $1 / 4$ Alen paa Afstand fra Baggrunden, hvorved det arkitoniske Forhold udvider sig i Dybden, og Skyggerne bliver stærkere. Der blev Plads til 10 ret store Billeder. Paa det største (Nadveren) er Ansigterne de samme som i Magstrup. - Hvorfor man kasserede denne Altertavle i Øsby, kan jeg ikke sige. Mennesker ved ikke altid, hvad de gør.

Den næste Altertavle, som kom fra Værkstedet $i$ Segeberg, var bestemt til Starup, hvor den smukke Prædikestol allerede havde sin Plads. Her var i Modsætning til Øsby Pladsen snever og ringe. Mesteren maatte knække sin Tommestok et Par Led tilbage. Det lykkedes ham at tegne et Hele, som er ualmindeligt godt sammenstemt. Og saa maalte han Dybden endnu rigere end i Stepping og Øsby. Loftet over Nadverbordet bag de to slanke Søjler blev til en stjernebesat Himmel. Ogsaa denne Altertavle har maattet vandre og staar nu i Vojens Kirke. Værket er blevet grundigt istandsat og iklædt sine straalende Farver i lidt dæmpet Aftoning, og nu staar det i sin beskedne Stolthed lige for Menighedens Øjne i det nye lyse Kirkerum. Ingen har sagt, at det ikke evner at fylde den Plads, det er sat paa. Dette er det smukkeste Vidnesbyrd om, hvorledes Hans Dreyer forstod sig paa sin Kunst og sin Opgave. Den Haand, der formaaede at skabe et Værk, som frydede den kristne Menighed i 300 Aar for derefter i genfodt Skikkelse at fryde nye slingter maaske $i$ andre 300 Aar, den Haand er ikke at foragte. Vi føler en vis Tilfredsstillelse ved, at der endnu staar under Foden af de statelige Søjler, om ikke Kunstnerens Navn, saa dog de klare Ord: ANNO 1615. Lad det dristige og 
løbske 20. Aarhundrede flittigt se paa dette Tal og bøje sit Hoved.

Jeg vil formode, at den gamle Altertavle i Gammelhaderslev, som Haupt henfører til 1609, og maaske baade Altertavle og Prædikestol i Vonsbæk er udførte omkring 1615.

Hvad der blev udrettet paa Værkstedet i det folgende Aar, ved jeg ikke. Men inde i Stuerne i Hjemmet hørtes en ny Røst. Mester Hans har taget sig en Hustru igen, og hun hedder Anna Martens. Vi ønsker ham hjertelig til Lykke, thi det er ikke godt at være alene, allermindst naar man engang har været to.

Anna Martens drømte vist ikke om, hvilken Storhed hun gik ind til, og at det skulde komme saa svimlende hurtigt. Det var i det lykkelige og uforglemmelige Aar 1617, at Anna Martens blev Kongelig Hofbilledskærerfrue i Haderslev.

Farvel Segeberg! Farvel I gode Madammer i Lybæks gamle Snedkerlav! Farvel I ringe Dage! En straalende Fremtid lyser i Nord. Kanske hendes Førstefødte skal se Dagens Lys paa Kongens eget Slot.

Ja saamænd. Der var paa Haderslevhus baade Glassers Kammer, Schniders Kammer og Schnickers hus. Til al Overflod nævnes $i$ et Inventarium fra 1127: Hanns Dreier sin Kammer, itzo des hausvoigts kammer. Tænkte vi det ikke nok.

Ak nej, Anna Martens, det er bare Spøgeri altsammen.

Dette Kammer bærer allerede samme Navn i et Inventarium af 13. Okt. 1593. Men da kan Hans Dreyer næppe have været i Haderslev. I en Forteg- 
nelse over Slottets Haandværkere fra samme Tidsrum finder vi ham heller ikke.") Desuden har vel ingen paa Slottet eller i Byen kaldt ham Hanns Dreier. Baade han selv og andre brugte stadigt Betegnelsen Hans Bildensnider.

Lad saa den Fugl flyve.

Der blev nok en Lejlighed til Familjen paa Katsund blandt andre smaa kongelige Embedsmænd. Skattelisterne i Raadstuearkivet gaar kun tilbage til Tredivetallet og giver ingen Oplysninger; de omfatter heller jkke Slotsgrunden.

I det hele taget var Herligheden med den kongelige Stilling kun ringe. Beskikkelsesbrevet for Hans Dreyer har jeg ikke kunnet finde. Men fra Aaret 1639 har man endnu et saadant Brev, ifølge hvilket "wir unsern lieben getreuen Peder Wolff für unsern Hofftischlern allhie auf unserem Hause gnedigst bestellt und angenohmen.« - Han skal have $20 \mathrm{Rdl}$. Løn aarligt og desuden Dagløn. Det maa være omtrent de samme Vilkaar, man har budt Billedskæreren.

Om de Arbejder, Hans Dreyer fik Lov at udfore for Kongen, lader jeg Amtsregnskaberne tale.")

Efter en Regning for 1616:17 er der gjort 6 nye Vindueskarme paa Slottet - - Item Wdskoret et parti (?) paa den Nii Vandkunst i yrtehaffuen. Wdi K. M. Køken det store Skab med nii lage forferdiget, imodt K. M. Ankumpst gemakerne med Klede bedraget och opslaget och Atskillige benke och sengsteder till rette fliet och ombfløtt effter $\mathrm{K}$. M. egen befalning

*) Alle disse Inventarier er cffentliggjorte af Hans Berlage i Zeitschrift d. Ges. f. Schlesw. Holst. Geschichte B. 53. 54 (Das Schloss Hansburg).

*) Haderslevhus Regnskaber i Rigsarkivet 1616/17 ff. 
gjort II Schriine, som vdj Kircken bleff nedersatt till K. M. Seng giordt II Sengeheste - - 3 smaa Foder till at pakke Spejgelle udj - udj Her Statholders kammer ett Skjermbredt. Ialt 30 Dages Arbejde.

Fra samme Aar: M Hanns Bildensnider och Snitker hannem fornøjet med efftern. Summa for efftern. Arbeidt giort till K. M. Jagthus udi Boldersleff. Først 8 nii Sengsteder giort och 4 gamel Sengsteder som alldelis vaar i Sønder och fran Anden igien till Rette fliet och forbederrit. 3 schiffver och 11 Schabelstolle med Ryggelehen i ligemaade paa Niies giordt, desligeste tvo dørre for tvende hemmeligheder - Item en schiffue som kand Vddrages wid begge Ender. - - Ialt 48 Dage.

Item haffuer forb. $H$. Bildensnider werret udj Skougen och ladet tømmer hugge 28 Dage.

Denne. Sysselsættelse, som i Aarenes Løb ikke blev større men mindre, var ikke nok til at ernære en Mand med hans Familie. Men det behøvedes heller ikke. Thi Hans Dreyer vedblev, som vi skal se, at forsyne Kirker og Herregaarde med sin Kunst. Endnu i 1617 blev der sat en ny Prædikestol i Magstrup. Den er ikke mere i Behold, men der kan vist ikke være nogen Tvivl om, at den har været udført af samme Mand, som for syv Aar siden gjorde Altertavlen samme Sted.

Paa Museet i Kolding opbevares en Prædikestol, som bærer 'Aarstallet 1618. I Fyldningerne er Kristus og de fire Evangelister malede, ogsaa her er Kristus fremstillet med Rigsæble og oprakte Fingre. Lydhimlen har de sædvanlige Kartuchegavle. Ogsaa Lydhimlen over den gamle Prædikestol i Stepping Kirke har Tallet 1618. 
Paa Amtsstuen lød Afregningen for 1617/18 saaledes: M. Hans Bildensnider och Snitker hannem fornøjet och betallet for efftern. Arbeidt giort udj Hadersleff ladgardtt etc Forst till det nye porthus Saa vell och dett nij halfftag thersammestets det Aar bleff opbüggett giort VI nii dørre och dessen tilbehøring. Sambledis giort et Koren-Seef bruges i ladgarden Att rengiøre Kornet medt - - och ellers adskillige flickeri giort paa ladgarden - Ialt 17 Dage. Paa Slottet var der gjort 9 Dages Arbejde: Først udj det store Taarn saa och paa Kornlofftet nii Vinduer - - Item imod de Gottorpske herrers Ankumpst saa vell och mod den Sverrigs Fyrstes Ankumpst gemakerne tvende gang med klede bedraget - sengsteder fløttet. -

Lidt mere var der at bestille det næste Aar, dog kun ialt 48 Dage. Men da han til Tider havde 4 Svende med sig, kunde der jo udrettes en Del. Imod Bichopffuen von Feerden ankumpst maatte gemakkerne have den sædvanlige Omgang, Sengesteder flyttes fra et Kammer til et andet, Stole og Bænke forsynes med Ryglæne og forbedres. Ligesaa ved Kongens Ankomst, efftersom Allehaande flickeri $\mathrm{Udj}$ saa maade fornøden giøres. Deslige for K. M. Instrumentister twende Instrument foder giordt. Saa wel och for K. M. Sølffuerpap trende Sølffuer foder Udbederet. Saa och K. M. Kolkøkenkorff(?) som aldelis huor isønder paa Niies igien forfærdiget - -

I det følgende Aars Tid nævnes Hans Dreyer ikke i Regnskaberne. Jeg tænker, han da har været hos Holger Rosenkrants paa Fyn (Dalum). Imidlertid har Varkstedet dog besørget adskilligt i Nordslesvig. Saaledes blev der i Dalby rejst en Altertavle af 
ret enkle Former med Aarstallet 1619. Den staar nu i Kolding Museum og mangler kun passende Farver for at kunne gøre Fyldest $\mathrm{i}$ en hvilken som helst mindre Kirke. Paa Loftet i Jegerup Kirke ligger en Del Stumper af en Altertavle, som har staaet nede $i$ Koret, men maatte vige for den nuverende fra Øsby. Den stammer fra 1620, og et Par liggende Figurer er nojagtig de samme som i Magstrup, hvortil Jegerup lengang var Anneks. En tredje Altertavle bærer Aarstallet 1619 og staar nu i den mærkelige, gamle Kirke i Hjerting, men skal før have staaet i Hygum, lige uden for Haderslev Provstis Crænser. Denne Altertavle er ikke saa lidt forskellig fra den Gruppe, vi her har for $\emptyset \mathrm{je}$, men det forekommer mig dog troligt, at den maa være bygget af Hans Dreyers Folk. Trættes vil jeg ikke med nogen om den Sag.

Om Prædikestolen i Aastrup bemærker Haupt, at den ligner den Starupper. I Virkeligheden er de meget forskellige, idet den Aastrupper horer til den enkle Type, vi har set i Kolding Museum. Men Professor Haupt har aabenbart haft en Fornemmelse af, at der var et Slægtskab imellem de to, hvilket der ogsaa sikkert er. Lydhimlen bærer et C 4 og Tallet 1621. Selve Prædikestolen har hverken Figurer eller Billeder, men sikkert har Kristus og de fire Evangelister været malede $\mathrm{i}$ dens Felter. Det hele er et smukt Stykke Arbejde.

Paa sanıme Tid har Mesteren bl, a. til K. M. Jagthus i Bollersløff for hoybemellte Hanns May Gemack giortt ett portaal ganske paa nii, desuden twende portaaler af yge och fürbreder. Paa Slottet har han ikke udrettet noget $i$ et Aars Tid. Det er sansynligt, at Eske Brok har trængt til ham nogle Maaneder. 
I Koret i Hoptrup Kirke hænger et Gravmæle, som skulde være til Ihukommelse af en Ridefoged og hans Hustru, men nu indeholder Prasternes Navne. Det blev færdigt 1623. Paa Slottet var der Arbejae i 21 Dage.

Den største Opgave fik Hans Dreyer betroet i det næstfølgende Aar. Da arbejdede Hans Bildensnider medt Bildensnider Swenne længere Tid paa Slottet. Efftersom det Karnapp paa Slottet hvis panell ganske med alle huor forraaddent. Saa er det nu udj steden effter K. M. nadigste Befaling medt bildensnider Arbeiclt och udskorne angesichter pa nii igien med al desse tilbehor bekled och fofærdiget. Mesteren arbejdede i 112 Dage. Hans 4 Svende hed Davit Knegt, Hans Knegt, Jorgen Snitker, Jesper Snitker. Fra Værkstedet afleveredes desuden en stor og prægtig Altertavle til Bjært Kirke. Den er 1915 undergaaet en kostbar Restavration, men den var det værd. Som den staar nu, behersker den med sine kraftige Omrids og straalende Farver hele det store Kirkerum. Mange af dens Enkeltheder minder stærkt om Altertavlen i Magstrup.

Her standser Hans Dreyers Kirkearbejde i Sønderjylland for en lang Tid. En Del udaterede Arbejder maa vel ogsaa have været fuldførte paa dette Tidspunkt.

Paa Haderslevhus har han endnu udfort adskillige Smaating indtil 1625-26, derefter endnu giortt ett kammer udi K. M. borgestuffue, hvorfor han modtager Betaling mod egenhændig Kvittering d. 12. Nov. 1630. Han underskrev da for sidste Gang:

Hans bylden Schnyder Egen handt. 
Men om Værkstedet eller Familien da endnu fandtes i Haderslev, er meget tvivlsomt. I Efteraaret 1627 bredte Wallensteins Tropper sig op ad Østkysten. En stor Del af Haderslev By brændte, deriblandt 40 Huse i Katsund foran Slottet.

Og hvem kunde nu have Brug for en Billedskærer?

I Ligtalen siges, at Mester Hans arbejdede 2 Aar for Frans Rantzau i København, som blev Statholder og Rigsraad 1627 og døde 1632. Da Arbejdet i Holckenhavn begyndte senest 1031, maa Hans Dreyer have været i København 1627-29(30).

Men inden vi flytter bort fra de slesvigske Egne, maa vi i det mindste registrere en Del Arbejder, som jeg mener bør tilskrives det samme Værskted, uden at jeg ser mig i Stand til at oplyse noget om deres Alder. Det er, foruden hvad der allerede er omtalt, ved Gammelhaderslev og Vonsbæk, en Altertavle i Moltrup og ligeledes en i Annekssognet Bjerning; en Altertavle i Hoptrup af samme Grundrids som i Stepping og Vojens (Starup); en Altertavle i Fjelstrup, som ikke synes bevaret i sin oprindelige Skikkelse, og en Prædikestol samme Sted med en ejendommelig tandsnitprydet Lydhimmel; en Prædikestol i Jegerup, som nu ikke eksisterer mere; en Prædikestol paa Museet i Kolding, som er berøvet sine Søjler og som menes at stamme fra Hejls. I Tørninglen Provsti har jeg set en Altertavle, som jeg uden Betænkning anser for Dreyers Arbejde, nemlig i Toftlund Kirke, der nu er prægtigt restaureret. Det er det eneste Stykke fra hans Værksted, som maa siges ikke mere at gøre Fyldest under de nuværende 
Forhold. I Gram staar en Altertavle, som muligvis hører til samme Familie.

Jeg formoder, at alle disse Arbejder har været færdige, før Hans Dreyer forlod Haderslev.

Hvad Kunstneren fik at bestille hos Frans Rantzau i København, der var trolovet med Kristian IV's Datter med Kirsten Munk, kan jeg ikke give nogen Oplysning om. Alt, hvad vi véd om hans mangeaarige Virksomhed paa Øerne, indskrænker sig væsentligt til Holckenhavn ved Nyborg.

Det var Ellen Marsvins Gaard. Hun kaldte den med fuld Føje Ellensborg; thi hun lod bygge den største Part af den. Paa den ene Fløj staar endnu: Eline Marsvin 1631. I den Fløj findes Kapellet, som indeholder Hans Dreyers betydeligste Arbejde. Ligtalen fortæller, at han brugte 7 Aar dertil. Da Bygningen var færdig 1631, og Kapellet indviedes i December 1637, maa Arbejdet være foregaaet i det mellemliggende Tidsrum. En af Bænkene bærer ogsaa Aarstallet 1634.

Det har taget lang Tid, inden man i Danmark er blevet klar over, hvem der har skabt Indretningen i Ellen Marsvins Kapel. Det er den svenske Professor Otte Rydbeck, som i sit smukke Værk "Två märkliga kunstnärer" (Stockholm 1918) paa fyldestgørende Maade har redegjort for Træskærerarbejdets Tilblivelse.")

Omkring Aar 1630 arbejdede en ukendt Kunstner, som en enkelt Gang har betegnet sig selv med

*) Foranstaaende maa ikke misforstaas, som om det var Svenskeren, der maatte fortælle os i Danmark, hvem der har skabt hele Udstyret i hapellet. At Hans Dreyer var Mester for Hovedparten, var opdaget og eftervist af Dr. Mackeprang. 
Bogstaverne A. S., i Skaane. Han udførte flere Prædikestole, deriblandt en til Kapellet paa Borsjøgaard, der ejedes af Otto Marsvin, Broder til Ellen Marsvin. Fra denne Mesters Haand stammer ogsaa Prædikestolen i Holckenhavn. Dette Stykke, som maa kaldes det smukkeste og værdifuldeste af hele Indretningen, er altsaa ikke af Dreyer. Og den Sammenligning, som nu bliver uundgaaelig, bliver $\mathbf{i}$ den Grad til Fordel for den ubekendte A. S., at vor nordslesvigske Billedskærer kommer til at staa helt i Skyggen.

For Rydbeck bliver Hans Dreyer til en ringe Kunstner, som han hver Gang omtaler med en vis Angst for at spendere for megen Anerkendelse paa ham. Jeg skal anføre nogle af de Udtalelser, der af Hensyn til det foreliggende Emne kunde interessere os mest:

"Den ene, Borsjömästaren A. S., har utfört indredningens mästerverk, predikstolen med dess baldakin, medan den andre, Hans Dreyer*) förfärdigat hela den öfriga indredningen, häri inbegripat pedikstolens trappa, dör och panelverk, ja - - t. o. m. nogra detajlfigurer å själfva predikstolen.« (Desuden er nogle Statuetter af A. S.) Om de Englefigurer, $\mathbf{H}$. Dreyer anbragte paa selve Prædikestolen hedder det: "Deras yttre röjer samma bristande kännedom om människokroppens anatomi, som de flesta öfriga figurarne å de med bildverk och ornament öfverlastade inventarierna i Holckenhavns kapell. Dessa skralt udförda putti äro Hans Dreyers från Eckernförde verk!«

*) Det skal hemarkes, at H. Dreyer ikke er den anden af Bogens to mærkelige Kunstnere. For Forfatteren er H. Dr. aldeles ikke nogen mærkelig Kunstner. 
»Det er ej blott i modelleringen af det nakna som mästaren A. S. är Hans Dreyer öfverlägsen. Den förras mjuka, skickliga dräcktbehandling öfverträffar vida den senares, hvars oroliga gropiga formlöshet ej tager hänsyn till den under dräkten befintliga människokroppen. I fråga om ornamentiken kan Borsjömästarens obestritliga öfverlägsenhet likaledes häfdas, fastän äfvan Dreyer på sina ställen åstedkommit smakfulla, dekorativa fyllingar. Den öfverlastade, ofta vårdslöst udfürda ornamentik, hvilken karakteriserar största delen av Holckenhavnsinredningen, torde därför i afsevärd grad böra tillskrifvas de medhjälpare, Dreyer säkerligen haft och i sanningens interresse bör äfven framhållas, at de svaraste försyndelser i fråga om figurplastiken, som man tilllåtit sig i denna indredning, tvifvelsutan härröra från dessa medhjälpera. Om man således måste medge, att Dreyer ej var någon skicklig plastiker, så bör man å andra sidan erkänna, att han i fråga om kompositionsförmåga och fantasi i viss mån motsvarade det eftermäle han fått $i$ den förnt omnämnda likpredikan.«

Inden Forfatteren kommer til Ende med sin Afhandling, kommer han dog endnu i Tanker om, at »i betraktande af den ovanliga prakt och den öfverflödande fantasirikdom, hvarmed Holckenhavnsinredningen smyckat“, er det muligvis ogsaa A. S., som har leveret det første Udkast til det hele.

Efter denne slemme Medfart kan Hans Dreyer trænge til lidt Oprejsning, og jeg vilde ønske, at jeg kunde give ham den.

Lidt opmuntrende er det at læse, hvad William Norvin skriver i Værket "Danske Herregaarde ved 
1920 " om Kapellet i Holckenhavn. Dets Inventarium »er et af de mest storslaaede Træskærerarbejder, der

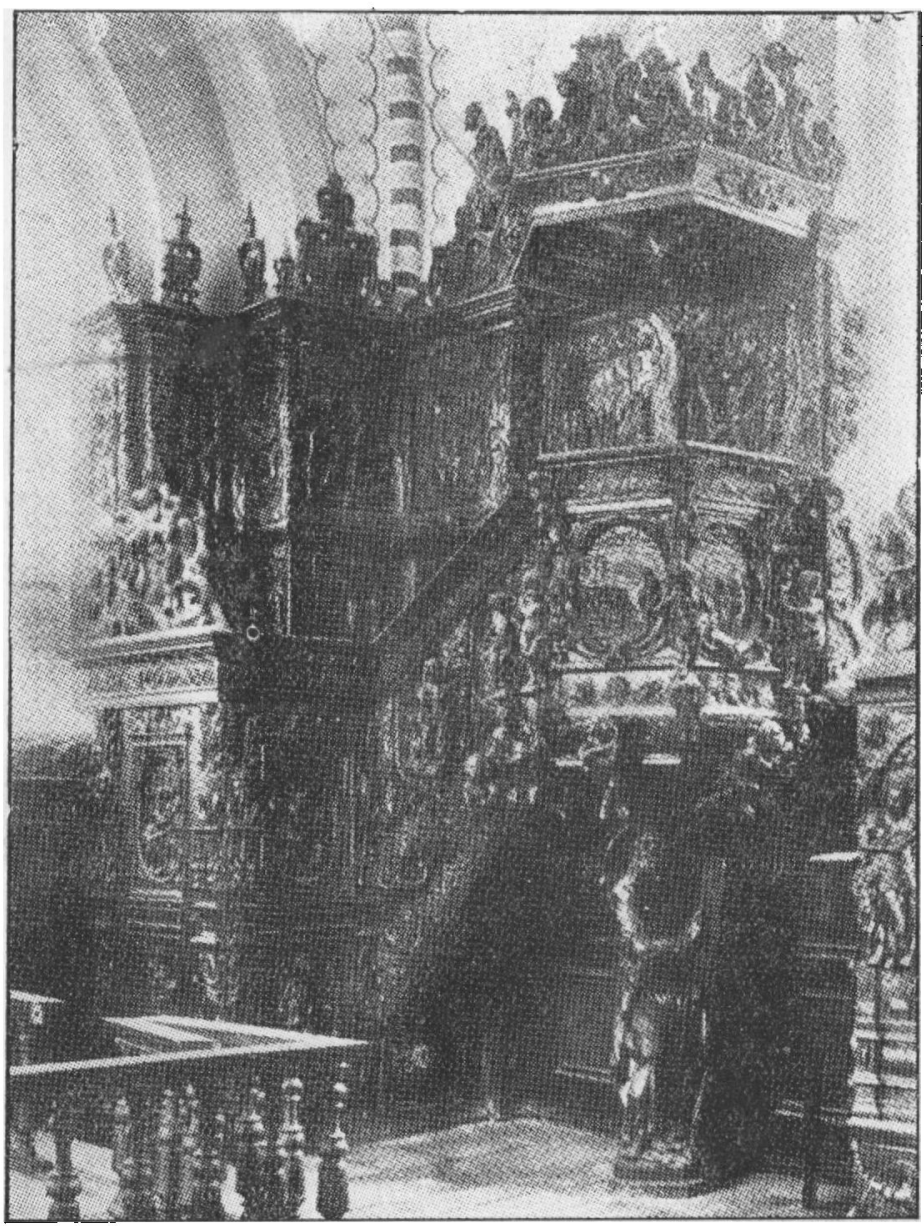

Prodikestolen ved Holckenhavns Kapel.

findes her i Landet«. "Et rent Pragtstykke», hedder det, "er Prædikestolen med Indgangsdør, Opgang, Rygpaneler og Lydhimmel, som alt er dækket af udskaarne Fremstillinger af bibelske Scener, Evangeli- 
ster, musicerende Engle og svavende, rent dekorative Putter; saa overlæsset dette ægte Barokværk end kan virke, kan man dog, naar man tager det nærmere $\mathrm{i} \emptyset$ jesyn, ikke andet end glæde sig over de mange nydelige Enkeltheder. Ogsaa Stolestaderne, forst og fremmest Herskabsstolene, er rigt smykkede med Udskxringer, baade Figurer og Ornamenter i Stil og Udførelse ganske svarende til og lige saa mesterligt udført som Prædikestolens Arbejde. Mesteren for hele dette Arbejde hed Hans Dreyer."

Men desværre maa jeg finde denne Lovtale lige saa ufortjent som Prof. Rydbecks bedske Kritik.

Hvem der har set de ovenomtalte Arbejder i de slesvigske Kirker og ladet sig overbevise om, at de stammer fra Dreyers Værksted, træder ikke ind i Holckenhavns Kapel med store Forventninger. Man undrer sig ikke det mindste over den Mangel paa Kendskab til det menneskelige Legeme, som Rydbeck - og forresten Mag. C. A. Jensen før ham - har opdaget i Udskæringsarbejlet. Jeg har i disse Kirker ikke fundet en eneste Figur, som forraadte noget sandt Mesterskab. Derfor bliver det forste Indtryk af Kapellet tværtimod det: at al denne Herlighed overgaar Mester Hans' Evner. Men alt som man ser nærmere efter og opdager de talrige Svagheder i Arbejdet, ja maaske uvilkaarligt gør Sammenligning med den fremmede Mesters Kunst paa selve Prædikestolen, tror man mere og mere at kunne spore samme Haand som i Starup Kirke ved Haderslev. Her er de fire Evangelister igen, siddende ved deres Bord med Dug og Pult paa og med Bøger i Baggrunden. Vi har her paa Stolestaderne de plattyske Indskrifter, der minder starkt oin den Mester, der aldrig skrev Dansk 
paa noget Arbejde i Sønderjylland, men derimod en enkelt Gang Tysk. Og vi møder her - hvad der gor

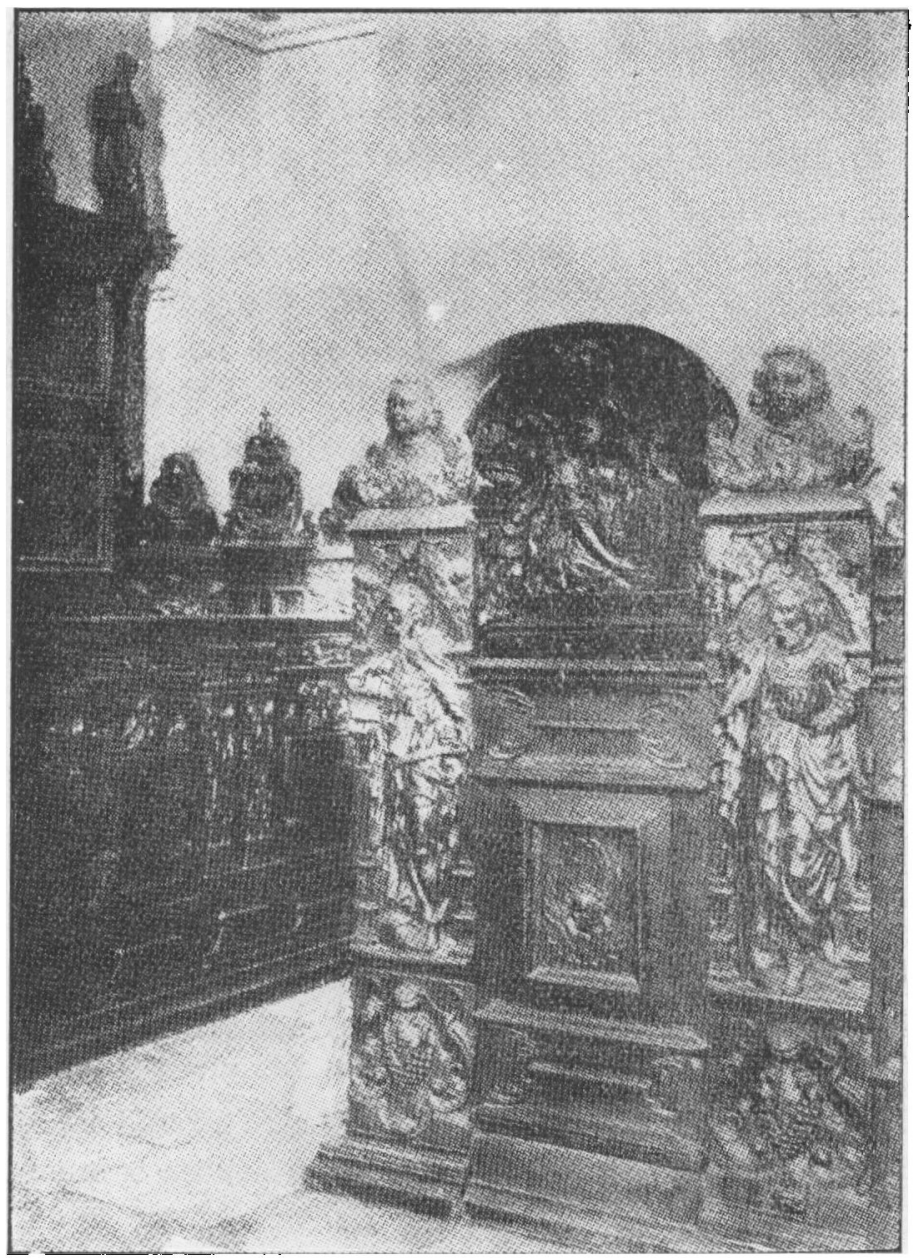

Stolestaderne i Holckenhavns Kapel.

Ende paa min Tvivl - den Kristusskikkelse, som vi kender saa godt fra flere Arbejder i Haderslevs Om- 
egn med nojagtigt samme Holdning og den selvsamme ejendommelige Straaleglorie.

Vender man sig saa om og betragter en Stund Kapellets kunstneriske Udstyr i sin Helhed, vil man ikke kunne nægte, at man staar omgivet af en frodig og skabelysten Fantasis Gerninger. Der er simpelthen ikke et eneste stykke ubeskaaret Træ at se i Rummet. Langs med Midtergangen staar paa Stolestadernes høje Gavlstykker de dybt skaarne Fremstillinger af Jesus og de 12 Apostle, som i en festlig Procession, i nasten Legemshojule. Disse Statuers stolte Ripkke indledes af nogle Reliefstykker af Jesu Historie. Men ogsaa paa Bagsiden af Gavlstykkerne fincles Srener af Jesu Liv fremstillede i Relief.' Ialt taller man i Kapellet 40-50 udskaarne Fyldinger med 10-20 Figurer paa hver. Det er umuligt at tage disse Stykker frem til Behandling enkeltvis. Desuden ser vi nogle kraftige Profetskikkelser paa Herskabsstolene og paa Fronten af Stolestaderne en Række kristelige Dyder. Rundt paa Væggen krones og samles hele Værket af en Panelering med mange store og smaa Ansigter eller Masker.

Dette er nu i sin Helhed Hans Dreyers Arbejde. Saa forfejlet det kan være i Enkeltheder, fylder det dog Rummet med en højtidelig Stemning. Det hele er barok, men Linjerne er ikke i den Grad kunstlede og forvredne, at de virker uroligt og unaturligt. Der er Kraft og Bevægelse i Formerne, Ensartethed og Harmoni i Sammenstillingen, Rigdom og Overflod baade $i$ det figurlige og ornamentale. Man skal ikke nedsætte dette Arbejde med den overlegne Bemærkning, som nu tilsyneladende alle har gjort, at det er overlæsset og overdaadigt. Langt mindre vil jeg ind- 
rømme Sandsynligheden for, at en fremmed Mester skal have skabt Planen til hele Værket. Der er ikke den ringeste Grund til at berøve Mester Hans denne Ere. Han har ved sine mange Altertavler vist, at en arkitektonisk Gruppering som i Holckenhavn laa fuldtud inden for hans Evners Rækkevidde.

I dette Øjeblik er det let nok at skelne mellem den dygtige $A$. $s$. og den mindre dygtige Hans Dreyer, men den Dag, Ellen Marsvin fik sit nye, smukke Kapel indviet, tror jeg, hun har været lige saa glad ved den sidste som ved den første.

Opholdet $i$ Holckenhavn maa have været til Ende 1637. Fra dette Tidspunkt til Kunstmerens Død formaar jeg ikke at opgive bestemte Data undtagen en Virksomhed paa 3 Aar hos Frans Lykke paa Fyn, som maa henlægges til Tiden omkring 1649-51. Det ligger nær at antage, at den gamle har tilbragt det meste af sine sidste Aar paa Fyn. Et Skab, hvoraf nogle Stykker for nylig er købt af Nationalmuseet, bærer Aarstallet 1642 samt Vaabenmærke og Bogstaverne E. W. Det har aabenbart tilhørt Erik Waldendorf og stammer fra Glorup. Af en Dor paa Holstenshus (Finstrup), sonı nu er brænclt, ejer Museet kun et Fotografi.

Men paa den gamle Arbejdsmark i Haderslev Provsti findes endnu nogle Billedskærerarbejder, som jeg ikke godt kan tænke mig udført af andre end Dreyer.

Saaledes fik Kirken i Aastrup en ny Altertavle 1638. Den er et Renaissancearbejde som alle de andre, men som om Erindringen fra Holckenhavn stod $\mathbf{i}$ Baggrunden læser vi hos Haupt den korte Bemarkning: Barok tritt eben ein. Kristusfiguren med den 
bekendte Straaleglorie staar i Midten. Forovrigt bærer hele Arbejdet Præg af en større Evne til at beregne de enkelte Deles gensidige Forhold, idet der findes anvendt en Slags perspektivisk Forkortelse nedenfra opad. De mange Englehoveder, som forneden er smaa Barneansigter bliver $i$ de overste Partier Ilæsten til Prikker.

Aaret efter maa Altertavlen i Oksenvad være rejst. L'malet som den er, viser den finere Enkeltheder ent alle de andre, men den er abenbart undergaaet saa nange Forbedringer og Istandsættelser, at man vanskeligt kan skønne, luvad der oprindeligt maatte stamme fra Hans Dreyers Haand. Man fristes til at tænke, at da Sonnen var Prast der paa Stedet, maatte det vare mere end sandsynligt, at den gamle Fader har smykket hans Kirke. Men efter Præstetavlen i Kirken, er Mag. Petrus Dreyer forst kommen til Oksenvad 1648. Da havde Altertavlen altsaa staaet en halv Snes Aar.

Tilbage er endnu to Prædikestole i de ganle Søsterkirker Moltrup og Bjerning, som Sognene lod udfore omkring 1(i49. Haupt finder, de ligner hinanden; jeg finder det ikke, men bojer mig for den kyndige, isaer da det passer saa godt i mit Kram, og jeg helst vil tilskrive samme Mester begge Arbejder.

Men under Betragtningen af disse sidste Ting staar vi igen over for den Gaalle i Hans Dreyers Liv, som vi mødte straks i Begyndelsen. Den kyndige Kunsthistoriker vil hævde, at det ikke er helt ualmindeligt, at en Kunstner optager en ny Stil i.sit . Arbejde (som da Dreyer gik fra Renaissance til Barok), men at en Tilbagevenden til den forste saa er meget usandsynlig ja nasten utrnkelig (at altsaa 
Dreyer efter Holckenhavnperioden skulde have leveret Renaissancearbejder i Nordslesvig).

Rigtigheden i denne Tankegang er vist indlysende for enhver. Men Livet bevæger sig, soin vi alle ved, ikke altid efter den almindelige Skolelogik. Mig forekommer det meget vanskeligere at tænke mig Kunstnerens Bevægelser fra Sønderjylland til Holckenhavn end den omvendte. Arbejdet paa Fyn $i$ det hele taget er af en saa ganske anden Art end hvad vi kender fra Egnen omkring Haderslev. Hvis vi til Sammenligning ejede en eneste Panelfylding fra Haderslevhus eller en Kiste fra en Bondegaard men jeg kender intet.

At dog ogsaa andre Kunstmere kan stille den sene Forsker over for lignende Gaader, har vi ved et mærkeligt Tilfælde netop et Eksempel paa i Holckenhavn. Ingen anden end den her ofte næunte Forfatter af Bogen om de två märkliga konstnärer maa nemlig om den meget lovpriste Billedskærer A. S. tilstaa, at hans Frembringelser er ellers of te hverandre saa ulige, at man til en Begyndelse har svært ved at tanke sig dem udfort af samme Mand. Hvad der da maa gælde for den ene Kunstner i Holckenhavn, skulde det være noget utænkeligt for den anden?

Idet jeg slutter denne korte Fremstilling, skal jeg give et lille Overblik over de af Hans Dreyer udforte Arbejder.

Der er udgaaet fra hans Værksted henved 20 Altertavler og 13 Prædikestole. Af Haderslev Provstis 33 Kirker var 20-25 smykkede med Arbejder fra hans Haand, nogle af dem har den Dag i Dag ikke andet Billedskærerarbejde end, hvad Dreyer har skabt. Men foruden disse os bekendte Sager har der 
sikkert været mange andre baade i Kirker og Bonderhjem. I Sommersted, Tyrstrup og Jels er de gamle Kirkebygninger forsvundne og dermed muligvis ogsaa, hvad der har været i dem af $H$. Dreyers kunst. Jeg tvivler ikke om, at der uden for det gamle Haderslev Provsti vil findes adskilligt mere af kirkeligt Udstyr fra hans Haand,end hvad jeg har set.

Tager vi hertil det store Arbejde i Holckenhavn, saa har vi allerede i den endnu eksisterende Part af $H$. Dreyers Gerning en saa rig og fyldig Samling af Billedskærerværk fra en og samme Haand, som det vel sjældent findes. Og saa har vi dog næsten intet set af, hvad han fik udfort i Omegnen af Segeberg og paa Haderslevhus eller de mange Herregaarde rundt om i hele Danmark, langt mindre hvad han inaa have udrettet $\mathrm{i}$ sin Vandretid gennem Tyskland. Det er vist ikke for meget sagt, at selv om det, der lier er bleven omtalt, er det bedste og værdifuldeste af, hvad den gamle Kunstner efterlod sig, saa har hele Massen af hans og hans Medhjælperes Arbejder sikkert været mindst dobbelt saa stor.

Iblandt dem, der skrev Sorgedigte ved Hans Dreyers Død, var en Student fra Lybæk. Han skrev blandt andet:

Nur alles Stückwerk ist ob man gleich horh begeistert, Mit grosser Kunst der Welt und alles übermeistert; die Erd und Würmer doch erzeigen ihren Lauff, Sie fressen beides Werk und auch den Meister auff. Der viele Tausend Stück der Bilder hinterlassen Giebt seines Lebens Bild den Würmern allermaassen.

Den unge Digter har talt i Tidens Sprog, men der er maaske ikke saa stor en Overdrivelse $i$, at den af- 
døde Mester efterlod sig Billeder og Figurer - smaat og stort - i Tusindvis.

Hans Dreyer var en flittig Mand, virksom incltil det sidste, en from og stærk Natur, en hæderlig og fornem Karakter.

Han døde i høj Alderdom i Oksenvad Præstegaard. I Kirkebogen for Aar 1ti53 staar der:

D. 4. Jan. imellem 4 og $5 \mathrm{om}$ affen dode nin s. Fader M Hanns Dreyer udi Oxenvad, 81 Aar ganmmel, begrafuet 7. Jan. ofuer hannem prædickede $H$ Peder Wandel udi Máustrup oc ligger begrafuet udi Kirken ved Præstegaardens Stoel, hoffdet vest for ved, oc fødderne til alterit. Gud give hannem en glædelig opstandelse.

Sønnen Mag. Petrus Dreyer flygtede i Svenskekrigen til Haderslev, hvor han hjalp Præsterne med at begrave de mange dode, og vendte ikke mere tilbage til Oksenvad.

Samtidig eller dog delvis samtidig med. Hans Dreyer levede og virkede de kendte Mestre Heinrich Ringeling i Flensborg og Gudewert, Fader og Son, i Eckernforde. Skulde nogen af disse tænkes at have paavirket Dreyer, maatte det være Ringeling. En Ringelingsk og en Dreyersk Altertavle er som to seystre. Heinrich Ringeling døde i København 1629, just paa den Tid, da Hans Dreyer maa have opholdt sig paa samme Sted. De maa vel da have mødtes.

Om disse fire slesvigske Mestre kan siges, at Hans Dreyer uden Tvivl overgik de andre $i$ uopslidelig Arbejdskraft og Skabelyst, medens han ikke naaede nogen af dem i ren kunstnerisk Dygtighed. 